\title{
An Investigation into the Biochemical Effects of Barbaloin on Renal Tissue in Cecal Ligation and Puncture-Induced Polymicrobial Sepsis Model in Rats
}

\author{
๑ Ayhan Tanyeli, ${ }^{1}$ ㄷ Derya Güzel²
}

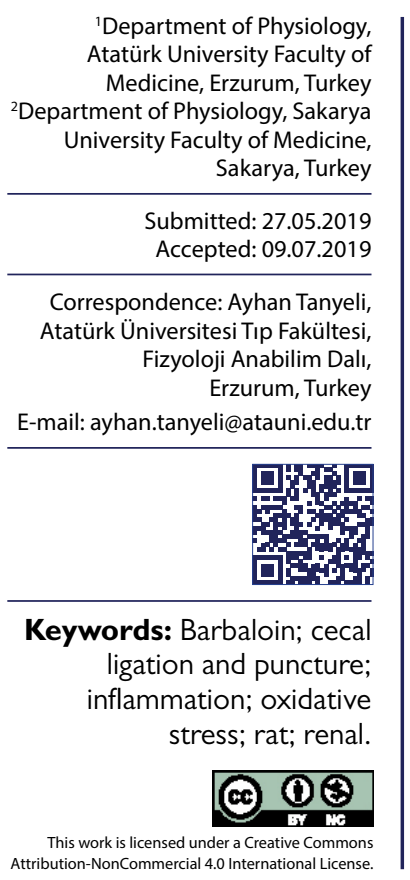

\section{INTRODUCTION}

Sepsis, due to multiorgan failure, ${ }^{[1,2]}$ causes death in intensive care units as high as $20 \%$ worldwide $^{[3-5]}$ because mortality rates are extremely high and it is important to investigate the sepsis with appropriate experimental models. The most commonly used model for experimental sepsis is the cecal ligation and puncture (CLP) model. [6,7] Inflammation plays an important role in the etiology and prognosis of sepsis. With the release of proinflammatory cytokines, such as tumor necrosis factor- $\alpha$ (TNF- $\alpha$ ), the severity of the inflammatory response increases. ${ }^{[8,9]}$ With cytokines and leukocyte activation, inflammatory responses are exacerbated, and organ damage occurs. The most important role in tissue damage is the releasing of oxidative molecules. ${ }^{[10]}$
Because of the oxidative stress, tissue damage occurs due to the decrease of antioxidant molecules that arise from increased reactive oxygen species (ROS) and nitrogen. ${ }^{\left[{ }^{\prime \prime}\right]}$ An increase in ROS causes lipid and protein peroxidation to enhance malondialdehyde (MDA), the fatty acid peroxidation product. ${ }^{[12,13]}$ Myeloperoxidase (MPO) is an indicator of neutrophils concentration in damaged tissues. [14] While the total antioxidant level (TAS) is used as an indicator of total antioxidant activity, total oxidant status (TOS) is a strong marker to determine total oxidant status. Oxidative stress index (OSI) is a value indicating the balance in the current oxidative status. ${ }^{[15,16]}$

Barbaloin is a molecule derived from Aloe vera. According to the literature, barbaloin has many pharmacological effects, including antioxidant, anti-inflammatory and antitumor properties. ${ }^{[17]}$ In the present study, we aimed to 
evaluate the effects of barbaloin, which has various biological properties, such as antioxidant, anti-inflammatory on renal tissue, to alleviate the oxidative damage in the CLP-induced polymicrobial sepsis in rats.

\section{MATERIALS AND METHODS}

\section{Laboratory conditions and drugs}

The present study was carried out in our University Experimental Animal Research and Application Center, our University Faculty of Medicine, Department of Physiology. This study has also been approved by our university Experimental Animals Local Ethics Committee (no. 28.03.2019/59). All rats were kept in the laboratory environment a 12-night/I2-day, with a humidity of $55 \%$ and a mean temperature of 21 degrees. Experimental animals were fed with standard pellet feed and water. However, all rats were starved before 12 hours from the experiment. Ketamine (from Ketalar ${ }^{\circledR}$, Pfizer, Istanbul), Xylazine (from Rompun $^{\circledR}$, Bayer, Istanbul) were used during the sacrifice. Barbaloin was supplied by Sigma-Aldrich Co, USA.

\section{Experimental animals and experimental design}

In this study, 32 healthy Sprague Dawley male rats (230$260 \mathrm{gr}$ ) were used. The rats were randomly divided into four groups. The formation of groups and the applications were as follows. Group I (Sham control group, $n=8$ ): We reached the peritoneum with a $2 \mathrm{~cm}$ incision from the abdominal area of the rats, and they were closed with a suture without any procedure and treatment. Group 2 (CLP group, $n=8$ ): The cecum was isolated by reaching the peritoneum with a $2 \mathrm{~cm}$ incision from the abdominal area of the rat, and the ileocecal valve was ligated up to $2 \mathrm{~cm}$ distal, then, it was pierced by 18-gauge needle ( 4 holes), the cecum was put back the abdomen and abdomen was closed with 3.0 silk suture. Group 3 (DMSO + CLP group, $\mathrm{n}=8$ ): Surgical procedures were performed as in Group 2. The DMSO was administered by oral gavage for five days. The final application was performed just before the CLP model. Group 4 (20 mg/kg barbaloin + CLP group, $\mathrm{n}=8)$ : Surgical procedures were performed as in Group 2. Barbaloin was administered by oral gavage for five days. The final application was performed just before the CLP model. In all groups the abdominal region was washed with povidone-iodine after being shaved. Analgesic lidocaine solution was applied to the suture areas of the rats to remove the error margin that might be caused by pain stress. The rats were deprived of food postoperatively but had free access to water for 18 hours until they were sacrificed.

\section{Biochemical analysis of renal tissues}

After the tissues were homogenized, all biochemical analyses were carried out in supernatants from homogenized tissues. In renal tissue samples, the MDA level to define lipid peroxidation status according to the method presented by Ohkawa et al., ${ }^{[18]}$ were measured. The results were given as $\mu \mathrm{mol} / \mathrm{g}$ protein. the MDA level was analyzed using the superoxide dismutase (SOD) activity specification protocol detected by Sun et al. ${ }^{[19]}$ SOD activity results of tissue samples were given as U/mg protein. MPO activity of the renal tissue was measured using a method improved by Bradley et al. ${ }^{[20]}$ The results of MPO activity were presented as U/g protein. TOS measurement was performed with a commercially available kit (Rel Assay Diagnostics). TAS value was evaluated with commercial kit (Rel Assay Diagnostics). TAS and TOS results were presented as $\mathrm{nmol} / \mathrm{L}$. The ratio of TOS to TAS was accepted as the OSI. OSI value was detected as follows: OSI = [(TOS, $\mu \mathrm{mol}$ $\mathrm{H}_{2} \mathrm{O}_{2}$ equivalent/L)/(TAS, mmol Trolox equivalent/L) $\left.\times 10\right]$. TNF- $\alpha$ and interleukin-I $\beta$ (IL-I $\beta$ ) levels were determined with a commercially available kit (Elabscience, Wuhan, China).

\section{Statistical analysis}

The results obtained from the experiments were given as mean \pm standard deviation (S.D.). P-values below 0.05 were considered statistically significant. The comparisons between groups were made according to One-Way ANOVA and Bonferroni test.

\section{RESULTS}

There has been no morbidity or mortality in rats during experimental applications. When CLP group compared to sham control group, TAS (from $261.917 \pm 24.628$ to $160.309 \pm 30.273, p=0.000$ ) level decreased, whereas TOS (from $96.542 \pm 13.268$ to $167.174 \pm 17.454, p=0.000$ ), OSI (from $0.037 \pm 0.006$ to $0.108 \pm 0.027, p=0.000$ ) levels increased. When barbaloin treatment group compared to CLP group, TAS (from 160.309 \pm 30.273 to $254.709 \pm$ I I. I 07 , $\mathrm{P}=0.000$ ) level increased, while TOS (from I67.174 \pm 17.454 to $97.327 \pm 7.205, p=0.000$ ), OSI (from $0.108 \pm 0.027$ to $0.038 \pm 0.003, p=0.000)$ levels decreased. There was no statistically significant difference between CLP and DMSO + CLP groups in terms of TAS, TOS and OSI.

When the CLP group compared to sham control group, SOD (from 2.432 \pm 0.094 to $0.728 \pm 0.072, p=0.000$ ) level decreased, while MPO (from 6.079 \pm 0.519 to $10.015 \pm 0.980, p=0.000$ ), MDA (from $0.233 \pm 0.043$ to I. 3 I $2 \pm 0.2 \mid 3, p=0.000$ ), TNF- $\alpha$ (from I77| $5.030 \pm 732.057$ to $76336.300 \pm 5007.314, \quad p=0.002$ ), and IL-I $\beta$ (from $22440.47 I \pm \mid 277.683$ to $8867 \mid .906 \pm 5321.605, p=0.002$ ) levels increased. When barbaloin treatment group compared to CLP group, while the level of SOD (from $0.728 \pm 0.072$ to $2.495 \pm 0.360, p=0.003$ ) increased, MPO (from $10.015 \pm 0.980$ to $6.406 \pm 1.095, p=0.000$ ), MDA (from $1.312 \pm 0.213$ to $0.247 \pm 0.057, p=0.000$ ), TNF- $\alpha$ (from I77I5.030 \pm 732.057 to $21186.340 \pm 1585.869$, $\mathrm{P}=0.000$ ), and $\mathrm{IL}-\mathrm{I} \beta$ (from 8867I.906 \pm 5321.605 to 24554.486 $\pm 1590.800, p=0.000$ ) levels decreased. There was no statistically significant difference between CLP and DMSO + CLP groups concerning SOD, MPO, MDA, TNF- $\alpha$ and IL-I $\beta$. When the results are evaluated, a great 
Table I. Comparisons of TAS, TOS and OSI levels among the experimental groups

\begin{tabular}{lccr}
\hline Experimental groups $(\mathbf{n}=\mathbf{8})$ & TAS (nmol/L) & TOS (nmol/L) & OSI (arbitrary unit) \\
\hline Sham control (I) & $261.917 \pm 24.628$ & $96.542 \pm 13.268$ & $0.037 \pm 0.006$ \\
CLP (2) & $160.309 \pm 30.273$ & $167.174 \pm 17.454$ & $0.108 \pm 0.027$ \\
DMSO+CLP (3) & $153.063 \pm 6.316$ & $169.096 \pm 17.049$ & $0.110 \pm 0.011$ \\
Barbaloin 20 mg/kg +CLP (4) & $254.709 \pm I 1.107$ & $97.327 \pm 7.205$ & $0.038 \pm 0.003$ \\
P-value (Meaningful intergroup comparisons) & $0.000(I-2)$ & $0.000(1-2)$ & $0.000(I-2)$ \\
& $0.000(1-3)$ & $0.000(1-3)$ & $0.000(1-3)$ \\
& $0.000(2-4)$ & $0.000(2-4)$ & $0.000(2-4)$ \\
\end{tabular}

TAS: Total Antioxidant Status; TOS: Total Oxidant Status; OSI: Oxidative Stress Index. Data are presented as mean \pm SD.

Table 2. Comparisons of other oxidative markers and cytokines among experimental groups

\begin{tabular}{|c|c|c|c|c|c|}
\hline $\begin{array}{l}\text { Experimental groups } \\
(\mathrm{n}=8)\end{array}$ & $\begin{array}{c}\text { SOD } \\
\text { (U/mg protein) }\end{array}$ & $\begin{array}{c}\text { MPO } \\
\text { (U/g protein) }\end{array}$ & $\begin{array}{c}\text { MDA } \\
\text { ( } \mu \mathrm{mol} / \mathrm{g} \text { protein) }\end{array}$ & $\begin{array}{c}\text { TNF- } \alpha \\
\text { (pg/mg protein) }\end{array}$ & $\begin{array}{c}\text { IL-I } \beta \\
\text { (pg/mg protein) }\end{array}$ \\
\hline Sham control (I) & $2.432 \pm 0.094$ & $6.079 \pm 0.519$ & $0.233 \pm 0.043$ & $|77| 5.030 \pm 732.057$ & $22440.47| \pm| 277.683$ \\
\hline CLP (2) & $0.728 \pm 0.072$ & $10.015 \pm 0.980$ & $1.312 \pm 0.213$ & $76336.300 \pm 5007.314$ & $88671.906 \pm 5321.605$ \\
\hline DMSO+CLP (3) & $0.77 I \pm 0.064$ & $10.019 \pm 1.218$ & $1.326 \pm 0.208$ & $79309.087 \pm 2867.28$ I & $9|450.243 \pm 4| 35.84 \mid$ \\
\hline Barbaloin $20 \mathrm{mg} / \mathrm{kg}+\mathrm{CLP}(4)$ & $2.495 \pm 0.360$ & $6.406 \pm 1.095$ & $0.247 \pm 0.057$ & $21186.340 \pm 1585.869$ & $24554.486 \pm 1590.800$ \\
\hline$P$ value (Meaningful & $0.000(I-2)$ & $0.000(I-2)$ & $0.000(I-2)$ & $0.000(I-2)$ & $0.000(I-2)$ \\
\hline \multirow[t]{4}{*}{ intergroup comparisons) } & $0.000(I-3)$ & $0.000(I-3)$ & $0.000(I-3)$ & $0.000(I-3)$ & $0.000(I-3)$ \\
\hline & $0.000(2-4)$ & $0.000(2-4)$ & $0.000(2-4)$ & $0.019(1-4)$ & $0.011(1-4)$ \\
\hline & $0.000(3-4)$ & $0.000(3-4)$ & $0.000(3-4)$ & $0.000(2-4)$ & $0.000(2-4)$ \\
\hline & & & & $0.000(3-4)$ & $0.000(3-4)$ \\
\hline
\end{tabular}

SOD: Superoxide Dismutase; MPO: Myeloperoxidase; MDA: Malondialdehyde; TNF- $\alpha$ : Tumor necrosis factor $\alpha$; IL-I $\beta$ : Interleukin-I beta. Data are presented as mean $\pm S D$.

similarity is observed between the sham control and barbaloin treatment group.

\section{DISCUSSION}

Sepsis is a host inflammatory reaction to infection leading to life-threatening multiorgan dysfunctions with high mortality rates (28\% to $50 \%$ ), and there are few options for its cure. ${ }^{[21-23]}$ World surgeons have been dealing with intraabdominal infections following gastrointestinal perforation complicating abdominal surgery. ${ }^{[2]}$ The sepsis has mortal complications, including septic shock, multiple organ dysfunction syndromes. ${ }^{[25,26]}$ Septic shock does progressive damage to lots of vital organs, including the liver, kidneys and heart, easily causing mortality in intensive care units. [21,27-29] The experimental and clinical data also reported that sepsis induces vital inflammation, such as acute kidney injury. ${ }^{[30,31]}$ TNF- $\alpha$ initiates the upregulation of cytokines and chemokines in an inflammatory cascade with its upstream role, but IL-I $\beta$ and IL- 6 are downstream molecules impairing the renal cells. ${ }^{[32]}$ CLP in rodents is told by researches as the 'gold standard' in the investigation of sepsis in a single animal model creating polymicrobial peritonitis. ${ }^{[7,33]}$

ROS attacks and does damages to macromolecules, such as membrane lipids, nucleic acids, carbohydrates, and pro- teins. TAS and TOS reflect the redox balance between oxidants and antioxidants. Measurement of the TAS indicates the activity of all antioxidants, while TOS is an indicator of ROS. ${ }^{[15,16]}$ In our study, these molecules changed in favor of antioxidation enzymes, such as SOD, protect tissue against oxidative damage. ${ }^{[34]}$ SOD is the most potent enzyme that scavenges superoxide anions. SOD and TAS decreased in CLP and DMSO+CLP group compared to sham control group in our study. MDA, reflecting the level of ROS produced by lipid oxidation, is the major product of the peroxidation process. To evaluate the level of oxidative stress, MDA and SOD are usually analyzed simultaneously. ${ }^{[35]}$ An oxidant parameter MDA is a toxic product generated during oxidation of the cellular membrane lipids by free oxygen radicals. ${ }^{[36,37]}$ Oxidized lipids and proteins and damaging cell membranes are associated with septic mortality. ${ }^{[38]}$ Antioxidant systems prevent oxidative damage in tissues dominated by oxidant mechanisms leading to lipid peroxidation through scavenging ROS. ${ }^{[39]}$ MDA in high levels exerts an increasing burden on urogenital system leading to renal function decline. ${ }^{[40]}$ MPO is an indicator of neutrophils that leak into tissue. TNF- $\alpha$ and IL-I $\beta$, which are released by the infiltrated neutrophils, ${ }^{[1,42]}$ are pro-inflammatory cytokines of this complex systemic inflammatory response. ${ }^{[43,44]}$ According 
to our results, these cytokines increased. There may be an inflammatory response in the pathogenesis of sepsis and associated with excessive production of cytokines. TNF- $\alpha$ plays a major role in the pathogenesis of an early phase of shock. ${ }^{[45,46]}$ Many barbaloin-related studies are available in the literature supporting the results of our study. In our study, reduction of levels of proinflammatory and oxidant parameters in septic rats by barbaloin, suggesting that barbaloin alleviated CLP-induced renal injury. Barbaloin has been demonstrated as protective of ischemic myocardial tissue in a rat model. ${ }^{[47]}$ Barbaloin has been reported to reduce the levels of intracellular ROS and inflammatory cytokines prevented lipopolysaccharide-induced acute lung injury. ${ }^{[48]}$ Barbaloin pretreatment has been shown to alleviate myocardial ischemia-reperfusion injury by antioxidant and anti-inflammatory effects. ${ }^{[17]}$ Barbaloin has been reported to have antiviral activity ${ }^{[49]}$ and anti-inflammatory ${ }^{[50]}$ property and may be used as a potential candidate for an alternative for antimicrobial therapy. Barbaloin has been shown to reduce inflammation and ROS formation in alcohol-mediated liver injury. ${ }^{[5]}$ In parallel with these studies, in our study, antioxidant and anti-inflammatory properties of barbaloin have been shown in CLP-induced polymicrobial sepsis model in rats. In the CLP group, TAS and SOD decreased while MDA, MPO, TNF- $\alpha$, IL-I $\beta$, TOS and OSI levels increased and barbaloin treatment reversed these levels. These data increase the potential of the drug to be used in the treatment of polymicrobial sepsis in the future to make effective changes in the clinical treatment of sepsis, the pathogenesis of cellular damage should be better understood. Clearly observed in sepsis studies is that inflammation, oxidative stress suppression can provide significant contributions to the treatment of sepsis. In the present study, inflammation, oxidative stress pathways are suppressed by barbaloin and this promises hope in the treatment of sepsis.

\section{CONCLUSION}

Barbaloin provides protection against renal damage by CLPinduced sepsis with its antioxidants and anti-inflammatory properties. We have indicated that treatment with barbaloin reduces renal damage in experimental animals exposed to CLP-induced polymicrobial sepsis model. Moreover, further studies are necessary to explain the other protective mechanism on CLP-induced renal tissue damage.

\section{Acknowledgement}

We would like to thank all participants for contributing to the present survey and also thanks Kardelen Erdoğan and Yaylagülü Yaman, undergraduates of our university Nursing Faculty, for their effort, help and support during the experiment.

\section{Ethics Committee Approval}

Approved by the local ethics committee.

Peer-review

Internally peer-reviewed.

\section{Authorship Contributions}

Concept: A.T., D.G.; Design: A.T., D.G.; Supervision: A.T., D.G.; Fundings: A.T., D.G.; Materials: A.T., D.G.; Data: A.T., D.G.; Analysis: A.T., D.G.; Literature search: A.T., D.G.; Writing: A.T., D.G.; Critical revision: A.T., D.G.

Conflict of Interest

None declared.

\section{REFERENCES}

1. Sluijter JP, Doevendans PA. Sepsis-associated cardiac dysfunction is controlled by small RNA molecules. J Mol Cell Cardiol 2016;97:67-9.

2. Kiers HD, Kox M, van der Heijden WA, Riksen NP, Pickkers P. Aspirin may improve outcome in sepsis by augmentation of the inflammatory response. Intensive Care Med 2016;42:1096. [CrossRef]

3. Suarez De La Rica A, Gilsanz F, Maseda E. Epidemiologic trends of sepsis in western countries. Ann Transl Med 2016;4:325. [CrossRef]

4. Liao X, Du B, Lu M, Wu M, Kang Y. Current epidemiology of sepsis in mainland China. Ann Transl Med 2016;4:324. [CrossRef]

5. Malacarne P, Langer M, Nascimben E, Moro ML, Giudici D, Lampati $\mathrm{L}$, et al. Building a continuous multicenter infection surveillance system in the intensive care unit: findings from the initial data set of 9,493 patients from 71 Italian intensive care units. Crit Care Med 2008;36:1105-13. [CrossRef]

6. Remick DG, Newcomb DE, Bolgos GL, Call DR. Comparison of the mortality and inflammatory response of two models of sepsis: lipopolysaccharide vs. cecal ligation and puncture. Shock 2000;13:110-6.

7. Buras JA, Holzmann B, Sitkovsky M. Animal models of sepsis: setting the stage. Nat Rev Drug Discov 2005;4:854-65. [CrossRef]

8. Reinhart K, Karzai W. Anti-tumor necrosis factor therapy in sepsis: update on clinical trials and lessons learned. Crit Care Med 2001;29:S121-5. [CrossRef]

9. Smith JA, Mayeux PR, Schnellmann RG. Delayed Mitogen-Activated Protein Kinase/Extracellular Signal-Regulated Kinase Inhibition by Trametinib Attenuates Systemic Inflammatory Responses and Multiple Organ Injury in Murine Sepsis. Crit Care Med 2016;44:e711-20.

10. Zhao H, Liu Z, Shen H, Jin S, Zhang S. Glycyrrhizic acid pretreatment prevents sepsis-induced acute kidney injury via suppressing inflammation, apoptosis and oxidative stress. Eur J Pharmacol 2016;781:92-9. [CrossRef]

11. Palipoch S. A review of oxidative stress in acute kidney injury: protective role of medicinal plants-derived antioxidants. Afr J Tradit Complement Altern Med 2013;10:88-93. [CrossRef]

12. Suliman HB, Carraway MS, Piantadosi CA. Postlipopolysaccharide oxidative damage of mitochondrial DNA. Am J Respir Crit Care Med 2003;167:570-9. [CrossRef]

13. Compton CN, Franko AP, Murray MT, Diebel LN, Dulchavsky SA. Signaling of apoptotic lung injury by lipid hydroperoxides. J Trauma 1998;44:783-8. [CrossRef]

14. Guo RF, Ward PA. Role of oxidants in lung injury during sepsis. Antioxid Redox Signal 2007;9:1991-2002. [CrossRef]

15. Rabus M, Demirbağ R, Sezen Y, Konukoğlu O, Yildiz A, Erel O, et al. Plasma and tissue oxidative stress index in patients with rheumatic and degenerative heart valve disease. Turk Kardiyol Dern Ars 2008;36:536-40.

16. Erel O. A new automated colorimetric method for measuring total oxidant status. Clin Biochem 2005;38:1103-11. [CrossRef]

17. Zhang P, Liu X, Huang G, Bai C, Zhang Z, Li H. Barbaloin pretreatment attenuates myocardial ischemia-reperfusion injury via activation of AMPK. Biochem Biophys Res Commun 2017;490:1215-20. 
18. Ohkawa H, Ohishi N, Yagi K. Assay for lipid peroxides in animal tissues by thiobarbituric acid reaction. Anal Biochem 1979;95:351-8.

19. Sun Y, Oberley LW, Li Y. A Simple Method for Clinical Assay of Superoxide-Dismutase. Clin Chem 1988;34:497-500.

20. Bradley PP, Priebat DA, Christensen RD, Rothstein G. Measurement of cutaneous inflammation: estimation of neutrophil content with an enzyme marker. J Invest Dermatol 1982;78:206-9. [CrossRef]

21. Singer M, Deutschman CS, Seymour CW, Shankar-Hari M, Annane D, Bauer M, et al. The Third International Consensus Definitions for Sepsis and Septic Shock (Sepsis-3). JAMA 2016;315:801-10.

22. Seymour CW, Liu VX, Iwashyna TJ, Brunkhorst FM, Rea TD, Scherag A, et al. Assessment of Clinical Criteria for Sepsis: For the Third International Consensus Definitions for Sepsis and Septic Shock (Sepsis-3). JAMA 2016;315:762-74. [CrossRef]

23. Rhodes A, Evans LE, Alhazzani W, Levy MM, Antonelli M, Ferrer R, et al. Surviving Sepsis Campaign: International Guidelines for Management of Sepsis and Septic Shock: 2016. Intensive Care Med 2017;43:304-77. [CrossRef]

24. Schrock TR, Deveney CW, Dunphy JE. Factor contributing to leakage of colonic anastomoses. Ann Surg 1973;177:513-8. [CrossRef]

25. Rossaint J, Zarbock A. Pathogenesis of Multiple Organ Failure in Sepsis. Critical Rev Immunol 2015;35:277-91. [CrossRef]

26. Sganga G. Surgical sepsis. Urologia 2015;82:75-83. [CrossRef]

27. Feihl F, Waeber B, Liaudet L. Is nitric oxide overproduction the target of choice for the management of septic shock? Pharmacol Ther 2001;91:179-213. [CrossRef]

28. Wickel DJ, Cheadle WG, Mercer-Jones MA, Garrison RN. Poor outcome from peritonitis is caused by disease acuity and organ failure, not recurrent peritoneal infection. Ann Surg 1997;225:744-53; discussion 53-6. [CrossRef]

29. Nesseler N, Launey Y, Aninat C, Morel F, Malledant Y, Seguin P. Clinical review: The liver in sepsis. Crit Care 2012;16:235. [CrossRef]

30. Angeli P, Tonon M, Pilutti C, Morando F, Piano S. Sepsis-induced acute kidney injury in patients with cirrhosis. Hepatol Int 2016;10:115-23. [CrossRef]

31. Gomez H, Ince C, De Backer D, Pickkers P, Payen D, Hotchkiss J, et al. A unified theory of sepsis-induced acute kidney injury: inflammation, microcirculatory dysfunction, bioenergetics, and the tubular cell adaptation to injury. Shock 2014;41:3-11. [CrossRef]

32. Okusa MD. The inflammatory cascade in acute ischemic renal failure. Nephron 2002;90:133-8. [CrossRef]

33. Hubbard WJ, Choudhry M, Schwacha MG, Kerby JD, Rue LW 3rd, Bland KI, et al. Cecal ligation and puncture. Shock 2005;24:52-7.

34. Halliwell B, Aeschbach R, Löliger J, Aruoma OI. The characterization of antioxidants. Food Chem Toxicol 1995;33:601-17. [CrossRef]

35. Fang YZ, Yang S, Wu G. Free radicals, antioxidants, and nutrition. Nutrition 2002;18:872-9, [CrossRef]
36. Yapca OE, Borekci B, Suleyman H. Ischemia-reperfusion damage. Eurasian J Med 2013;45:126-7. [CrossRef]

37. Del Maestro RF. An approach to free radicals in medicine and biology. Acta Physiol Scand Suppl 1980;492:153-68.

38. Ozturk E, Demirbilek S, Begec Z, Surucu M, Fadillioglu E, Kirimlioglu $\mathrm{H}$, et al. Does leflunomide attenuate the sepsis-induced acute lung injury? Pediatr Surg Int 2008;24:899-905. [CrossRef]

39. Lee DM, Hoffman WH, Carl GF, Khichi M, Cornwell PE. Lipid peroxidation and antioxidant vitamins prior to, during, and after correction of diabetic ketoacidosis. J Diabetes Complications 2002;16:294-300.

40. Li G, Chen Y, Hu H, Liu L, Hu X, Wang J, et al. Association between age-related decline of kidney function and plasma malondialdehyde. Rejuvenation Res 2012;15:257-64. [CrossRef]

41. Teoh N, Field J, Sutton J, Farrell G. Dual role of tumor necrosis factoralpha in hepatic ischemia-reperfusion injury: studies in tumor necrosis factor-alpha gene knockout mice. Hepatology 2004;39:412-21.

42. Wang Y, Wu S, Yu X, Zhou S, Ge M, Chi X, et al. Dexmedetomidine Protects Rat Liver against Ischemia-Reperfusion Injury Partly by the a2A-Adrenoceptor Subtype and the Mechanism Is Associated with the TLR4/NF-KB Pathway. Int J Mol Sci 2016;17.pii: E995.

43. Simpson SQ, Casey LC. Role of tumor necrosis factor in sepsis and acute lung injury. Crit Care Clin 1989;5:27-47. [CrossRef]

44. Bhatia M, Moochhala S. Role of inflammatory mediators in the pathophysiology of acute respiratory distress syndrome. J Pathol 2004;202:145-56. [CrossRef]

45. Bone RC. Immunologic dissonance: a continuing evolution in our understanding of the systemic inflammatory response syndrome (SIRS) and the multiple organ dysfunction syndrome (MODS). Ann Intern Med 1996;125:680-7. [CrossRef]

46. Bohannon J, Guo Y, Sherwood ER. The role of natural killer cells in the pathogenesis of sepsis: the ongoing enigma. Crit Care 2012;16:185.

47. Cui Y, Wang Y, Liu G. Protective effect of Barbaloin in a rat model of myocardial ischemia reperfusion injury through the regulation of the CNPY2-PERK pathway. I Int J Mol Med 2019;43:2015-23.

48. Jiang K, Guo S, Yang C, Yang J, Chen Y, Shaukat A, et al. Barbaloin protects against lipopolysaccharide (LPS)-induced acute lung injury by inhibiting the ROS-mediated PI3K/AKT/NF-kB pathway. Int Immunopharmacol 2018;64:140-50. [CrossRef]

49. Alves DS, Perez-Fons L, Estepa A, Micol V. Membrane-related effects underlying the biological activity of the anthraquinones emodin and barbaloin. Biochem Pharmacol 2004;68:549-61. [CrossRef]

50. Park MY, Kwon HJ, Sung MK. Evaluation of aloin and aloe-emodin as anti-inflammatory agents in aloe by using murine macrophages. Biosci Biotechnol Biochem 2009;73:828-32. [CrossRef]

51. Cui Y, Ye Q, Wang H, Li Y, Xia X, Yao W, et al. Aloin protects against chronic alcoholic liver injury via attenuating lipid accumulation, oxidative stress and inflammation in mice. Arch Pharm Res 2014;37:1624-33.

\section{Sıçanlarda Çekal Ligasyon ve Ponksiyon Kaynaklı Polimikrobiyal Sepsis Modelinde Barbaloinin Renal Doku Üzerindeki Biyokimyasal Etkilerinin İncelenmesi}

Amaç: Bu araştırmanın amacı barbaloinin çekal ligasyon ve ponksiyon (CLP) modeliyle böbrek üzerindeki yaralanmaya karşı koruyucu etkisini incelemektir.

Gereç ve Yöntem: Çalışmamızda hayvanlar dört gruba ayrıldı. Çalışma grupları şöyle tasarlandı; sham, CLP, DMSO+CLP ve 20 mg/kg barbaloin + CLP. Oksidatif stres ve sitokinler, deney sonunda elde edilen renal dokularda değerlendirildi.

Bulgular: CLP grubunda TOS, OSI, MPO, MDA, TNF- $\alpha$ ve IL-Iß’nin arttığı, TAS ve SOD'un azaldığı, ancak tedavi grubundaki değerlerin anlamlı olarak değiştiği bulundu.

Sonuç: Sonuçlarımız, barbaloinin CLP'nin neden olduğu polimikrobiyal sepsis modelinin neden olduğu böbrek hasarına karşı etkili olduğunu göstermiştir.

Anahtar Sözcükler: Barbaloin; böbrek; çekal ligasyon ve ponksiyon; enflamasyon; oksidatif stres; sıçan. 